\title{
THE CONCEPT OF "THE PRESENCE OF GOD"- A LINK BETWEEN MISSIONARY THEOLOGY AND CHRISTIAN SPIRITUALITY
}

\author{
Prof. Ph.D. David PESTROIU, \\ "Faculty of Orthodox Theology „Justinian the Patriarch”, University of Bucharest, \\ ROMANIA, \\ E-mail: pestroiu@gmail.com
}

\begin{abstract}
In a world of religious and moral dissolution, in which nihilist atheism and hedonistic consumerism prevail, missionary theology must propose to the secularized human the experience of reunion with God as a means of restarting the religious experience manifested concretely through prayer and intense spiritual life. Modernity has obviously fuelled deified conceptions, isolating God in an inaccessible transcendence, and promoting a total abandonment of the possibility of experiencing any form of real encounter with Him. The only way to get in touch with Him was rational knowledge, as it was found in the Bible, or logical deductions resulting from the dialogue between theology and science. But they dangerously lead to the postmodern concept of a God-idea, concept, force, etc., lacking the attribute of personality. According to Orthodox doctrine, God has a personal character, being, more specifically, a Trinity of Persons. Therefore, we find enough biblical and patristic grounds, all testifying to the existence of divine Presence. This Personal Presence is the basis of promoting an intense spiritual life of the faithful human, who is aware of the necessity of an organic bond with it, creating a true state of communion. It is, on the one hand, a personal relationship cultivated by every person through prayer, but also an inter-personal relationship created within the public cult, especially in the Divine Liturgy and the Holy Mysteries of the Church. The experience of Divine Presence as generated the consciousness of asceticism, consisting in desolation and climbing on the virtue scale, to perfection. The intense spiritual life, especially promoted in the monasteries, has led to the experience of awakeness as a work designed to transfigure human, who gives up on the comfort of the material world, preparing himself or herself for experiencing of the kingdom of God. In this study, I will present, on the one hand, the role of spirituality for missionary theology, starting from fulfilling the concrete experience of the Divine Presence, and on the other, I will seek raising awareness of the dangers of the false spiritualist movements promoted by the New Age movement and the rationalistic - anti-theistic concepts of postmodernity.
\end{abstract}

Keywords: Postmodernity; divine presence; theosis; orthodox spirituality;

\section{THE DISCOVERY OF GOD'S PRESENCE IN THE WORLD'S IMMANENCE - THE CORE OF ORTHODOX THEOLOGY AND SPIRITUALITY}


According to Orthodox teachings, The Triune God revealed Himself as the symbol of perfect communion. Father Dumitru Stăniloae called the Holy Trinity as "the structure of supreme love." ${ }^{1}$ Indeed, disinterested, sacrificial, merciful love (agape-in Greek) determined (caused) the creation of the world, the work of salvation, but also the perfection or sanctification of all creation. The new heaven and new earth expression describes this state of rebirth to a new life of communion with God through the restoration of man by Jesus Christ. Through His resurrection with flesh of glory, pneumatized, He gave human nature the purpose for which it was created, placing it on the right side of the Father.

Orthodoxy reveals God as close to people, not isolated in an inaccessible transcendence. Ever since creation, God entered into dialogue with man, giving him the status of intra-Trinitarian communion as an existential example. According to Orthodox theology, man was created after the image of God, but the likeness with God should be gained by personal effort. In the primordial state of the Eden Heaven man had to pass the exam of obedience to the divine commandment, in order to attain to the state of perfection, the deification through grace (theosis). It was also proof of the finalization of God's creation, which, in order to be perfect, had to be filtered through the mandatory condition of expressing free will.

The man made, however, another choice. His chance to reach the goal for which he was created (deification) has not changed, but the course has become more difficult. The human nature has been altered, heading for death as a payment of $\sin$ (Romans 6,23), but receives the hope of an eternal life, in the eschatological kingdom of the restored world.

The redemption of man was accomplished by the Savior promised by Proto-Gospel (Genesis 3, 15), Jesus Christ, the Son of God Incarnate, the palpable evidence of Divine Presence in the life of the world. About Him, the Apostle Paul affirms that He has given up divine glory, taking the form of a servant and a human face, showing the perfect divine love to the human race (Philippians 2, 7).

But even until Jesus Christ, God fully manifests his presence in the life of mankind, enlivening the passing through history of the chosen people, the guardian of the revelation of the motive and purpose of creation. In the Old Testament books, there are enough references to the real presence of God in the world, even after the eviction of the man in Eden.

\section{DIVINE PRESENCE IN THE OLD TESTAMENT}

God addresses Himself directly to the patriarchs and prophets, to whom he communicates His will and transmits His commandments, guiding them to perfection. The essential attribute of the divine mission in the Old Testament is to strengthen the theocracy and transmit the Messianic idea. The world, though imbruted by the consequences of sin, is sanctified by the presence of God.

The Holy Trinity is revealed to Patriarch Abraham at the oak tree of Mamvri, under the faces of the three young men, suggesting that the eternity of man restored in the relationship of perfect communion with God will be accomplished at the age of the young man. Jacob is shown the presence of God's glory in a night vision, in the form of a stairway that unites heaven with the earth upon which the angels ascend and descend. Eastern Patristic sees in this a prefiguration of the Church later on, and the very stairway is a prefiguration of the Mother of God. Things happen similarly on Horeb. There, the Mother of God is prefigured by the burning bush, and the presence of God offers the place a special

\footnotetext{
${ }^{1}$ See: Fr. Prof. Dumitru STĂNILOAE, „Sfânta Treime - structura supremei iubiri” (Holy Trinity - the Structure of the Supreme Love), in: Studii Teologice, 1970, Nr. 5-6, pp. 333-356.
} 
holiness, causing Moses to take his shoes off in respect. God's glory appeared and filled the temple of the Lord, and his altar, called the Holy of Holies, was considered to be the place of its dwelling, the place where God was present.

Through the theophanies and the angelophanies, God communicates his will and continuously guides his chosen ones. Noah is taught how to build his ark, Abraham is led to Canaan, his faith is tried, and God enters into an everlasting covenant with him and his descendants, Moses is sent as a liberator from the Egyptian bondage, Samuel is entrusted with the task of establishing royalty, through the presence of the Lord's anointed, great and small prophets are sent to preach and proclaim the will of God. These are only a few examples of the many similarities that the Bible sets, in order to prove to the utmost that the monotheistic religion of the Old Covenant was guided directly by God, who coordinated its history.

\section{DIVINE PRESENCE IN THE NEW TESTAMENT}

In the New Testament, God descends into the world through His Incarnate Son, the Divine Logos Jesus Christ, and the restorer of fallen human nature. If until now God's presence was only made in a syncopated way, He becomes present through the incarnation of Christ, and remains present in the eternal world; and, behold, I remain with you until the end of the world (Matthew 28,20). He does not only offer the great commandment of love, but exemplifies it by the state of sacred communion, offering himself for men in the sacrifice of Golgotha, but also giving everyone the opportunity to unite with him through the Eucharist: Who eats My Flesh and drinks My Blood remains in me and I in him (John 6,56). Another chance to feel His presence is prayer made in the state of fellowship of others: Where are two or three are gathered in My Name, there I am in the midst of them (Matthew 18,20). Love as the foundation of communion is the foundation on which Christ builds His discourse that revolutionized history. The love for your enemies is a socio-communal concept so high that humanity has not been able to implement it in all the 2000 years since then, and it fails to do so even today. It is, however, the identity mark of the kingdom of heaven (Matthew 13, 11; Luke 8,10), which must be preached to all nations, becoming the ultimate goal of human existence. The Incarnation of the Word of God is considered by St. Paul the mystery that has been kept hidden for ages (Colossians 1,26-27), which is now revealed to all. In the face of the mythologies of antiquity, creations of the human mind to justify the desire for earthly hegemony of temporal leaders, the truth of God's immense love for His creation is now revealed and postulates a new world in which love and justice intertwine, as unique criteria of organization and leadership. "The importance of the embodiment of God's Son must be understood as the best way to redeem man, because sin and death have come into the world through one man (Adam), so redemption had to come through one man as well (the New Adam), who is God-Man, Jesus Christ, that is God's grace and his gift to the world should be abundant, through the embodiment, Death, and Resurrection of Christ"2. Thus, the Church is born - a theandric body in which Christ is continually present, enlivening and leading all the people who take shelter in it to the goal of salvation. St. Paul associates the Church with a body whose head is Christ, and we are members, each one (I Corinthians 12,27). He furthermore resembles the mystical connection between Christ and the Church to a wedding, thus symbolizing their indissoluble connection, united by love. The one who enlivens this divine-human synergistic osmosis is the Holy

\footnotetext{
2 Nicușor BELDIMAN, "Dogmatic teachings on the Persons of the Holy Trinity reflected in the works of the preachers from Muntenia in the $20^{\text {th }}$ century", in: International Journal of Orthodox Theology 7:1 (2016), p. 88.
} 
Spirit, which fills everything (Ephesians 4,10): The Spirit of God lives in you (Romans 8, 9). He makes Christ present in the Sacraments of the Church so that believers can themselves be part of the death and resurrection of Christ. For example, in the Sacrament of Baptism, the neophyte buries himself with Christ in the three-dip diving in the water, and then resurrects with Him when, from the bath of birth again, he rises holy to live with Him now. That is why the Apostle of the Gentiles exclaims: for all of you who were baptized into Christ have clothed yourselves with Christ (Galatians 3,27). He is aware of the presence of Christ in His being, transfigured and transformed by faith, grace and good deeds into the Church: I no longer live, but Christ lives in me (Galatians 2,20). Thus, Christian life is presented as a participation in the life of Christ: For to me, to live is Christ (Philippians 1,21) - says the same Apostle.

\section{DIVINE PRESENCE IN THE HISTORY OF THE CHURCH}

The establishment of the Christian Church in history is based on the consciousness of divine presence. The first centuries of Christianity are marked by the existence of martyrs who preferred to die and be with Christ rather than lose their salvation, leading a concupiscent life on Earth without Him. Moreover, the faith of the early Christians was heavily impregnated by the imminence of Parousia, and their experience was sincere in the form of an Eschaton before its time. The first martyr, Saint Stephen, in the moment of the sting of stoning, does not feel the pain of death-causing blows, but rejoices seeing the heavens opening up and the Son of Man to the right of the Father (Acts 7, 56). From there, the entire latter patristic theology is impregnated by the mystical experience: the meeting with God and experiencing his salvific presence. Through it, God directly unites with the righteous to whom He is revealed in His perfect form. Apostle Paul himself was abducted to the third heaven (1 Corinthians 12, 1-4).

St. Cyril of Alexandria interconnects mystic ecstasy of the knowledge of unapproachable light as a taboric experience: "The Son thus illuminates in a creative way, as He who is the True Light, and the creature is enlightened by participation in the Light. That is why it is called light, ascending higher than the human nature by grace that glorifies it and crowns it with various honors." ${ }^{3}$ Thus, according to Prof. Ullrich Zeitler, "it might be useful to distinguish between «spiritualizing» and «spirituality». While «spiritualizing» often is seen as a process that points to something beyond this world and in contrast with this world, «spirituality» - at least in Christian understanding - is related to an embodiment, an involvement in daily life." 4 To exemplify this kind of physical transformation, I chose the words of Blessed Augustine, full of deep mystical experience: "Late have I loved you, beauty so old and so new: late have I loved you. And see, you were within, and I was in the external world and sought you there, and in my unlovely state I plunged into those lovely created things which you made. You were with me, and I was not with you. The lovely things kept me far from you, though if they did not have their existence in you, they had no existence at all. You called and cried out loud and shattered my deafness. You were radiant and resplendent, you put to flight my blindness." A special relationship between restored humanity and

\footnotetext{
${ }^{3}$ St. CYRIL of Alexandria, Comentariu la Evanghelia Sf. Ioan (Comment on St John's Gospel), translation in Romanian by Fr. Prof. Dumitru Stăniloae, published by: Editura Institutului Biblic şi de Misiune al Bisericii Ortodoxe Române, Bucureşti, 2000, p. 91.

${ }^{4}$ Ullrich ZeITLER (ed.), Spirituality, Diaconia and Social Work, Publisher: Knowledge Center for Diaconia and Pedagogy, Diakonhøjskolen i Aarhus, Højbjerg, Denmark, 2012, p. 74.

5 Augustine, Confessiones, translation in Romanian by N. Barbu, published by: Editura Institutului Biblic şi de Misiune al Bisericii Ortodoxe Române, Bucureşti, 1983, p. 224.
} 
Christ, her Savior, also sees Origen, who identifies the meaning of the Son of God's kenosis - his descent into the world to lift it to the knowledge of divine light: "So did the Son also, when He got rid Himself of His equality with the Father, to show us the way of knowledge, thus becoming «the image of God», and we, who cannot look at the magnification of the preached Light that lies in the glory His deity, through the fact that Christ became His light for our sake, we got to see the divine light, contemplating its glory." 6

St. Athanasius the Great states, "We must not wonder if the Son speaks of His projection in us as He speaks of himself ..." And St. John Cassian discovers the valences of this relationship between the saved and the Savior, when he says, "Whoever has in Himself the fullness of the deity can gift to all from His fullness, the One in whom in the fullness of the deity dwells, He Himself dwells in each of the saints, which he counts as worthy of His dwelling, and, no matter how much He gives to all from His fullness, He Himself remains unceasingly in His fullness. Even while He was in His body on Earth, He was in the souls of all the saints, filled the heavens, the earth, the sea, all that exists with the endlessness of His power and magnification. He was so in Himself that the edges of the world could not encompass Him, because, however large and unsaid are the ones that have been made, yet none of them are stretched and unmeasured enough to encompass Their Maker ... "8 The key to understanding this synergic dwelling-place is love, as revealed by St. Maximus the Confessor: "Why do theologians call Godhead either eros or agape, either dear or loved. For on one hand it moves itself, on the other it just moves. Or to put it more clearly: as love and affection, divinity moves itself, and as a dear and loving it moves all those capable of love and affection closer to itself. And to make it even clearer: it moves as it plants the inner affection of love in those capable of it and moves as it attracts the desire of those who move through it. And again: it moves and moves, because it thirsts after its thirst, and loves to be loved ..."

As he himself promises, God is present in the world's immanence until the end of the ages. Commenting on this text, from Matthew 28, 20, St. John Chrysostom says: "Did you see the authority with which he spoke to them? Did you see that these words were spoken on the level of the apprentices' understanding? He did not say that he would be with them only, but with all the latter faithful believers - the apostles were not going to live until the end of time - he spoke to them as some who would make a single body with all the latter believers. The Lord said, "Do not talk to me about the burden of commission. I, who make everything lighter, am with you! " This is what he also often said to the prophets in the Old Testament: to Jeremiah, who put his youth before, and Moses and Ezekiel, who hesitated: I am with you! The same thing He now tells His disciples too." ${ }^{10}$

\footnotetext{
${ }^{6}$ ORIGEN, De principiis, translation in Romanian by Teodor Bodogae, published by: Editura Institutului Biblic şi de Misiune al Bisericii Ortodoxe Române, Bucureşti, 1982, p. 63.

${ }^{7}$ St. ATHANASIUS the Great, Trei cuvinte contra Arienilor (Three discourses against the Arians), in: Scrieripartea I (Writings - first part), translation in Romanian by Fr. Prof. Dumitru Stăniloae, published by: Editura Institutului Biblic şi de Misiune al Bisericii Ortodoxe Române, Bucureşti, 1987, p. 321.

${ }^{8}$ St. JoHn Cassian, Despre întruparea Cuvântului (About de Word's Incarnation), translation in Romanian by Vasile Cojocaru şi David Popescu, published by: Editura Institutului Biblic şi de Misiune al Bisericii Ortodoxe Române, Bucureşti, 1990, p. 821.

${ }^{9}$ St. MaXIMUS the Confessor, Ambigua, translation in Romanian by Fr. Prof. Dumitru Stăniloae, published by: Editura Institutului Biblic şi de Misiune al Bisericii Ortodoxe Române, Bucureşti, 1983, p. 229.

${ }^{10}$ St. JoHn Chrysostom, Comentariu la Evanghelia Sf. Matei (Comment on St Mathew's Gospel), translation in Romanian by Fr. Prof. Dumitru Fecioru, published by: Editura Institutului Biblic şi de Misiune al Bisericii Ortodoxe Române, Bucureşti, 1994, pp. 1001-1002.
} 
The place of the plenary meeting of man with God is the liturgical space. That is why St. Ambrose of Mediolanum states that where the Church officiates the Holy Sacraments, Christ Himself is present ${ }^{11}$.

\section{THE LITURGIC MYSTERY - THE PRESENCE OF GOD}

The whole set of cultic acts of Orthodoxy is centered on the need for mystical experience, as a way of blessing the man with divine grace. For orthodox people, grace is uncreated and not separated from God, sparking as an energy that illuminates, perfects and sanctifies the work of divine creation. God descends into the immanence of the world on the thread of uncreated divine energies, lifting people into the kingdom of heaven. That is why the Orthodox Liturgy begins with the blessing of "the Kingdom of the Father and the Son and the Holy Spirit", and a very beautiful hymn reads: "In the church of Your glory standing, in heaven we seem to be ..." The motivation of common prayer in Orthodoxy is therefore the creation of an interpersonal communion between God and man on one hand and between people all together on the other. John Meyendorff points out in this regard: "The conscious and personal experience of the Holy Spirit is therefore the supreme goal of Christian life in the Byzantine tradition, an experience which presupposes constant growth and ascent. This experience is not opposed to an essentially Christocentric understanding of the Gospel, for it itself is possible only "in Christ», i.e., through communion in the deified humanity of Jesus; nor is it contradictory to practical ethical requirements, for it remains impossible unless these requirements are fulfilled. But obviously, such experience reflects a basically personalistic understanding of Christianity."12

A great help in this process of spiritual becoming are the visual supports - the icons, the true windows to the heavens. According to Leonid Uspenski, they have a strong dogmatic and missionary role: "Only the Orthodox icon confesses fully to the Trinitarian iconomy, since the knowledge of God through the Incarnate Word (which is the face of the Father) is accomplished only by the iconomy of the Third Hypostasis of the Holy Trinity in the sacred light of the Pentecost. To such a testimony - which culminated in the hesychasm the ensemble of the artistic creation of the Church after the iconoclasm is oriented." ${ }^{13}$ The same author testifies about the confessing role of the icon: "The icon (modern or ancient) testifies to the salvation "prepared before all people, the existential realization that allowed the formation of the Church in the world», "light that glorifies the nations and the grace of the people», of the new Israel. Designed for the man, revelation is given to the Church and fulfilled through it, which is revealed to the world. And the image of the revelation which is brought to the world is that of the worshiped Body of Christ, the image of the Church itself, the testimony of faith and holiness within, testimony of the Church about itself. That is why the specific character of the Orthodox icon reveals the broad vision that brings together the past and the future in a continuous present. And, no matter how precarious the means are, the human creation serves the age to come." 14

\footnotetext{
${ }^{11}$ St. Ambrose of Mediolanum, Despre Sfintele Taine (About Holy Sacraments), translation in Romanian by Fr. Prof. Ene Branişte, published by: Editura Institutului Biblic şi de Misiune al Bisericii Ortodoxe Române, Bucureşti, 1994, p. 27.

12 John MEYENDORfF, Teologia bizantină (Byzantine Theology), translation in Romanian by Fr. Prof. Alexandru I. Stan, published by: Editura Institutului Biblic şi de Misiune al Bisericii Ortodoxe Române, Bucureşti, 1996, p. 237.

${ }^{13}$ Leonid UsPensKI, Teologia icoanei în Biserica Ortodoxă (Theology of the Icon in the Orthodox Church), translation in Romanian by Teodor Baconsky, published by Anastasia, Bucureşti, 1994, p. 210.

${ }^{14}$ Ibidem, p. 217.
} 
The function of liturgical language is, according to André Scrima, to always make God present ${ }^{15}$. That is why the Liturgy proposes a theological view on human life and is the source of the permanent experience of the Church in relation to the world, called to become the key to the kingdom of God. By participating in the Liturgy, man is fascinated by God's presence, circumscribed by space and time, while offering the chance of a spiritual elevation of the human being above the coordinates of his telluric existence, in order to experience the joys of eternal life. According to Father Mihai Himcinschi, "in the Liturgy, the Spirit does not descend because Christ is in heaven, to substitute Him on Earth, but to make Christ present through His Body and Blood on the Table of the Holy Altar under the image of bread and wine, which are given to all who come to Him with faith, full of the Holy Spirit."16 Thus, all those too small (Matthew 25, 40), having the image of Christ mirrored on their faces, create a state of communion starting from the Chalice.

The Church does not therefore show a dominant, triumphant attitude over men, but a merciful bent on their real, spiritual and bodily problems, giving them the necessary assistance to enter the kingdom of heaven. Social interactions, which are in a spectacular dynamic today, should not bypass the living, steady, presence of the Church, whose involvement in public life is more necessary than ever.

\section{THE ALLEGED DIVINE IMMANENCE OF FALSE ESOTERIC SPIRITUALITY IN THE POSTMODERN WORLD}

With the secularization of Western societies, there was an increased incidence of esoteric currents associated with the New Age movement. This confirms the man's thirst for the presence of God in his life. If Western Christianity has isolated God in transcendence, accentuating an unnatural separatism between Divinity and the created world, esoteric currents strongly promote the opposite: God is with the world, in the pantheistic manner promoted by oriental religions, syncretically imported into the secularized West. The idea that mankind needs a synthetic religion is accredited, and both Christianity and other religions are taken separately and considered to be outdated. The purpose of man is to evolve from the spiritual point of view under the direction of a master, and, through successive reincarnations, reach the state of Nirvana. Thus, appear the relativization of human life in flesh and the denial of the necessity of fulfilling moral norms that will be the object of divine judgment after death. Moreover, man's relationship with God is replaced by a surrogate relationship with a human person with alleged spiritual leader qualities, which often target merchant interests on the account of the naive in search of "masters." Here is one example, picked from a highly publicized source in post-communist Romania: "In order to obtain a clear vision of the Final Goal, it is essential to have a perfect GURU who knows every branch of the Four Ways of Initiation Rituals, without the slightest misunderstanding or doubt as to them. He can make the Final Goal perfectly explicit ..."17

Techniques of meditation or relaxation, yoga practice, the fake bio-energetic or reiki thaumaturgy have spread rapidly in the Christian area, benefiting from the support of new-

\footnotetext{
15 André SCRIMA, Biserica liturgică (The liturgical Church), translation in Romanian by Anca Manolescu, published by: Humanitas, București, 2005., p. 318.

${ }^{16}$ Fr. lect. dr. Mihai HIMCINSCHI, Biserica în societate. Aspecte misionare ale Bisericii în societatea actuală (The Church in society. Missional aspects of the Church in nowadays society), published by: Reîntregirea, Alba Iulia, 2006, p. 60.

17 Titi TudoranceA (coord.), Nirvana. Tehnici de Meditaţie (Nirvana. Meditation Technics), published by: Societatea Informaţia, Bucureşti, 1993, p. 108.
} 
agers, theosophists and anthroposophists who have sought to create sui-generis oriental and Christian doctrine combinations, stirring everything into a "religious soup" with fake, appealing flavors. Thus, Jesus Christ has descended, in turn, from the stature of the Son of God incarnate, at the level of a simple guru, with occult powers. In this regard, Prof. Michael Fuss warns: "The cosmic Christ, who appears as the solar Logos, is definitely not the biblical Jesus." ${ }^{18} \mathrm{He}$ also denounces "the conviction that the entire revelation of the historical Jesus is an applied oriental wisdom, ,inculturated” into the Palestinian context and hence at the roots of Christian tradition. Since the „Christ-consciousness” of Jesus of Nazareth was induced by Eastern mysticism, Christianity stands in a secondary position and transcends from the outset the boundaries of the Church, while the divine nature of the biblical Jesus is radically challenged. Here appears, vested in an attractive journalistic montage, a very concrete ,theology of religions”, at a time when the Church still has not fully faced up to these problems." 19

The main challenge of postmodernity on the anthropological plane is individualism, defined as the glorification of the self, to the detriment of God. Man has built his own autarchic, hedonistic and consumerist paradisiacal universe, fueled by pride and selfishness in the spiritual plane and opulence, wealth and technology facilities - in the material plane. In this respect, prof. Radu-Petre Mureşan's thoughts on pseudo-spiritual religious movements are very up to date: "Man establishes himself as the measure of all things. In these systems, Christ is not the one who saves man in the Church, but man strives to selfserve and self-justify without the grace of God. That is why all these groups and trends reject the Church and promote personal spiritual practices by using techniques and methods through which the subject keeps control of its inner evolution. However, these spiritual alternatives accommodate to the dominant religious culture, or at least there is no contradiction between the teachings they propagate and the religious environment from which the potential followers come from." ${ }^{20}$ The new humanism, also known as the "human potential movement," promotes the concept of a set of divinities, equal to the number of people on earth. They only need to discover and capitalize the inexhaustible potential of their demiurgical resources. In a similar way, with a science-fiction production color, Scientology is also expressed, considering humans the Thetans (extraterrestrials) who need help finding their own way to self-redeeming.

Prof. M. Fuss makes an exhaustive radiography of the branches of the New Age movement, which I will reproduce in the following part, since he describes synthetically its evolutionary spectrum: "Yet the most characteristical framework for the diffusion of New Age ideas is the "network». These groups include a broad range of associations and may be roughly listed under the following headings: a) in science: visionary physics («system of evolution»; "self-organization of the universe», global networking, holistic medicine, transpersonalistic psychology, thanatology; b) in society: alternative education, disarmament, feminism, ecology, soft technologies, New Age-management, new world order - Baha'i, body therapies, rebirth therapies, spiritual healing; c) in art: psychedelic music, overtone-singing, fantasy and science fiction literature; $d$ ) in spirituality: neo-cosmic

\footnotetext{
${ }^{18}$ Michael Fuss, "New Age and Europe. A Challenge for Theology", in: Michael A. Fuss (ed.), Rethinking New Religious Movements, Pontifical Gregorian University, Research Center on Cultures and Religions, Rome, 1998, p. 656.

${ }^{19}$ Ibidem, p. 657.

${ }^{20}$ Radu-Petre MuREŞAN, Alternative spirituale în România (Spiritual Alternatives in Romania), Agnos, Sibiu, 2011, p. 235.
} 
religiosity, gnostic-esoteric practices, natural mysticism (Find-horn), syncretistic gurus, channelling, belief in reincarnation and in extraterrestrial intelligences (UFOs), Eastern and theosophy-oriented groups" 21 .

What is most worrying is the fact that all of these mistakes receive pseudo-scientific coverage through their assumption by prestigious media channels, whether we are talking about printed press, radio or TV. In this respect, the finding of Rev. Dan Bădulescu is very pertinent: "If, until 1990, positivist and materialist science ignored and did not accept the supernatural, supersensual domain, today, through the so-called paranormal branch, these phenomena fall under the scope of research and the description of the scientific discourse. A testimony in this respect is, among other things, the satellite TV channel Discovery, a prestigious and authoritative channel in the field. In the last few years, this channel has programs with UFO scientific claims, unexplained mysteries, paranormal, astrology, poltergeist, life after life, etc. 2-3 times a week. These puzzles are no longer simply ignored as in the past but are approached from scientific positions." 22 It is clear that we are currently confronted with a truly manipulative offensive, supported by the media, to promote New Age occultism, rightly called false spiritual alternatives.

\section{CONCLUSION}

In this study, I have attempted to highlight the value of the Orthodox mystical spirituality, based on the Divine Revelation of the Old and New Testaments, as well as of the Holy Tradition, which postulate a living, dynamic and permanent relationship of man with God, embodied in prayer and living in the spirit of interpersonal communion that enlivens the Church. God descends into His creation today, being mysteriously present when invoked by the power of divine grace. Jesus Christ, the Son of God incarnate and the image of the Father, sacrifices himself in every Holy Liturgy, calling on the faithful to share with Him the Eucharist chalice. Furthermore, icons open true windows to the sky, providing the mystical experience of prayer meeting with those represented in the images. The experience of tremendousness, that is to say of the unceasing "prayer of the heart" ${ }^{23}$, especially in the monastic environment, gives the possibility of receiving the Tabor light in the soul, the mystical presence with Christ the Transfigured in glory, in the kingdom of the eternal happiness.

On the other hand, the false spiritualities of this passing age create confusion in a devastated world, where the concupiscent pleasures and the glorification of the human self are glorified, accentuating the abyss between man and God. Although strongly supported by the media, they all end by abandoning man to a selfish and individualistic loneliness, generating powerful convulsions of the human personality without communion. The technological conquests of the postmodern society, the moment of shine of ranks and riches, virtual online communication networks - all this cannot fill a man's ontological need of the life and love connection with God, his Creator and Savior. It is the task of the ecclesial mission to rebuild the bridge between the secularist man of today's time and the Church of Christ - the only one able to bring him to the living water of the kingdom of divine grace.

\footnotetext{
${ }^{21}$ M. FUSS, op. cit., p. 658.

${ }^{22}$ Fr. Dr. Dan BĂDULESCU, Impărăţia răului: New Age (The kingdom of Evil: New Age), Christiana, Bucureşti, 2001, p. 285.

${ }^{23}$ Also called: The Jesus Prayer: „Lord Jesus Christ, Son of God, have mercy of me, a sinner!”
} 


\section{BIBLIOGRAPHY:}

[1] AUGUSTINE, Confessiones, translation in Romanian by N. BARBU, published by: Editura Institutului Biblic şi de Misiune al Bisericii Ortodoxe Române, Bucureşti, 1983,

[2] BĂDULESCU, Fr. Dr. Dan, Impărăţia răului: New Age (The kingdom of Evil: New Age), Christiana, Bucureşti, 2001,

[3] BELDIMAN, Nicuşor, "Dogmatic Teachings on the Persons of the Holy Trinity Reflected in the Works of the Preachers from Muntenia in the $20^{\text {th }}$ century", in: International Journal of Orthodox Theology 7:1 (2016),

[4] FUSS, Michael,"New Age and Europe. A Challenge for Theology", in: Michael A. FUSS (ed.), Rethinking New Religious Movements, Pontifical Gregorian University, Research Center on Cultures and Religions, Rome, 1998,

[5] HIMCINSCHI, Fr. lect.. dr. Mihai, Biserica în societate. Aspecte misionare ale Bisericii în societatea actuală (The Church in society. Missional aspects of the Church in nowadays society), published by: Reîntregirea, Alba Iulia, 2006,

[6] MEYENDORFF, John, Teologia bizantină (Byzantine Theology), translation in Romanian by Fr. Prof. Alexandru I. STAN, published by: Editura Institutului Biblic şi de Misiune al Bisericii Ortodoxe Române, Bucureşti, 1996,

[7] MUREŞAN Radu Petre, Alternative spirituale în România (Spiritual Alternatives in Romania), Agnos, Sibiu, 2011,

[8] ORIGEN, De principiis, translation in Romanian by Teodor BODOGAE, published by: Editura Institutului Biblic şi de Misiune al Bisericii Ortodoxe Române, Bucureşti, 1982,

[9] SCRIMA, André, Biserica liturgică (The liturgical Church), translation in Romanian by Anca MANOLESCU, published by: Humanitas, București, 2005.

[10] St. AMBROSE of Mediolanum, Despre Sfintele Taine (About Holy Sacraments), translation in Romanian by Fr. Prof. Ene BRANIŞTE, published by: Editura Institutului Biblic şi de Misiune al Bisericii Ortodoxe Române, Bucureşti, 1994,

[11] St. ATHANASIUS the Great, Trei cuvinte contra Arienilor (Three discourses against the Arians), in: Scrieri - partea I (Writings - first part), translation in Romanian by Fr. Prof. Dumitru STĂNILOAE, published by: Editura Institutului Biblic şi de Misiune al Bisericii Ortodoxe Române, Bucureşti, 1987,

[12] St. CYRIL of Alexandria, Comentariu la Evanghelia Sf. Ioan (Comment on St John's Gospel), translation in Romanian by Fr. Prof. Dumitru STĂNILOAE, published by: Editura Institutului Biblic şi de Misiune al Bisericii Ortodoxe Române, Bucureşti, 2000,

[13] St. JOHN CASSIAN, Despre intruparea Cuvântului (About de Word's Incarnation), translation in Romanian by Vasile COJOCARU şi David POPESCU, published by: Editura Institutului Biblic şi de Misiune al Bisericii Ortodoxe Române, Bucureşti, 1990,

[14] St. JOHN CHRYSOSTOM, Comentariu la Evanghelia Sf. Matei (Comment on St Mathew's Gospel), translation in Romanian by Fr. Prof. Dumitru FECIORU, published by: Editura Institutului Biblic şi de Misiune al Bisericii Ortodoxe Române, Bucureşti, 1994,

[15] St. MAXIMUS the Confessor, Ambigua, translation in Romanian by Fr. Prof. Dumitru STĂNILOAE, published by: Editura Institutului Biblic şi de Misiune al Bisericii Ortodoxe Române, Bucureşti, 1983,

[16] STĂNILOAE, fr. prof. Dumitru, „Sfânta Treime - structura supremei iubiri” (Holy Trinity - the Structure of Supreme Love), in: Studii Teologice, 1970, Nr. 5-6,

[17] TUDORANCEA (coord.), Titi, Nirvana. Tehnici de Meditaţie (Nirvana. Meditation Technics), published by: Societatea Informaţia, București, 1993,

[18] USPENSKI, Leonid, Teologia icoanei în Biserica Ortodoxă (Theology of the Icon in the Orthodox Church), translation in Romanian by Teodor BACONSKY, published by Anastasia, Bucureşti, 1994,

[19] ZEITLER (ed.), Ullrich, Spirituality, Diaconia and Social Work, Publisher: Knowledge Center for Diaconia and Pedagogy, Diakonhøjskolen i Aarhus, Højbjerg, Denmark, 2012. 